\title{
Molecular Aspects of Schistosoma mansoni Female Maturation
}

\author{
Ana Lúcia Moraes Giannini, Sérgio Vasconcelos Linhares, Elena Cristina \\ Caride, Vania Maria Martins Braga, Franklin David Rumjanek ${ }^{+}$
}

\begin{abstract}
Departamento de Bioquimica Médica, ICB/CCS, Universidade Federal do Rio de Janeiro, Cidade Universitária, Ilha do Fundão, Caixa Postal 68041, 21941-590 Rio de Janeiro, RJ, Brasil
\end{abstract}

Incubation of total protein extracts of Schistosoma mansoni with ${ }^{3} \mathrm{H} 17-\beta$-estradiol and $20-$ hydroxyecdysone, revealed steroid binding proteins in both, male and female worms. The interaction of nuclear proteins with restriction fragments of the gender and stage-specific gene F-10 was investigated using the "Band-Shift" technique. Distinct male and female nuclear proteins bound to the fragments of this gene. Among the nuclear proteins, only those rich in cvsteine residues bound to DNA. In vitro incubation of live worms with the estrogen antagonist Tamoxifen, altered the pattern of the DNA binding proteins, producing in females, a band profile similar to that obtained with male worm protein extracts. When Tamoxifen was injected into schistosome infected mice, the eggs produced by females presented an abnormal morphology, compatible with non-viable eggs. These results suggest that the regulation of transcription of the $F-10$ gene might involve steroid receptors.

Key words: Schistosoma mansoni - nuclear proteins - F-l0 gene - steroid receptors - Tamoxifen - eggs

Based on the detection of consensus sequences present in stage and gender-specific genes of several species of schistosomes, the participation of regulatory proteins has been postulated (Bobek et al. 1989, 1991, Henkle et al. 1990. Chen et al. 1992). The downstream, non-translated region of the Schistosoma mansoni gene F-10 (Simpson et al. 1987, Kun $\%$ et al. 1987), is one such example, displaying a hexanucleotide and a pentanucleotide sequence, identical to hormone regulatory clements (HRE) present in genes regulated by steroids (Rumjanck et al. 1989).

Preliminary attempts to characterize $S$. mansoni F-10 binding proteins, showed that nuclear proteins bound to different restriction fragments of the F-10 gene (Engelender et al. 1993). The occurrence of steroids in S.mansoni (Nirde et al. 1983) supports the idea that among the DNA binding proteins steroid receptors could be present.

In the present work we have pursued this idea by carrying out experiments trying to verify: (a) whether estradiol and/or ecdysteroid binding proteins could be detected among the schistosome proteins; (b) whether the DNA binding proteins of S.mansoni shared some of the structural features

This work received financial support from the UDP/ World Bank/WHO Special Programme for Research and Training in Tropical Diseases, CNPq, CAPES, FINEP and The Rockfeller Foundation

'Corresponding author of steroid receptors: and (c) whether Tamoxifen, an estrogen antagonist could affect the development of eggs.

\section{MATERIALS AND METHODS}

Parasites - Adult S.mansoni worms were obtained by perfusion of Syrian hamsters using the methods described by Smithers and Terry (1965). The worms were separated by scx using a fine brush and were either uscd immediately or stored at $-70^{\circ} \mathrm{C}$. Protein extracts were obtained according to methods described elscwhere (Goodwin 1990) in the presence of protease inhibtors. Protein extracts were stored at $-70^{\circ} \mathrm{C}$. Protein concentration was estimated using the Lowry method (Lowry et al. 1951). Nuclear proteins rich in thiol groups were purified by affinity chromatography using AFFI-GEL 501 (BioRad) according to the manufacturer's recommendations.

Estradiol and Ecdysone Binding Assay - For the binding experiments, adult worms were homogenized in a Potter homogenizer in $10 \mathrm{mM}$ Tris- $\mathrm{HCl}, \mathrm{pH} 7,7.5 \mathrm{mM} \mathrm{MgCl} 2$ at $4^{\circ} \mathrm{C}$. The homogenate was centrifuged at $10,000 \mathrm{~g}$ for $3 \mathrm{~min}$ at $4^{\circ} \mathrm{C}$ and the supernatant collected, aliquoted and stored at $-70^{\circ} \mathrm{C}$ until used. The binding assay consisted of incubating $100 \mathrm{ml}$ of the protein extract in $10 \mathrm{mM}$ Tris buffer $\mathrm{pH} 7.7$ containing $0.25 \mathrm{M}$ sucrose and 1 mM EDTA, with $90 \mathrm{fmol}$ of 17 - $\beta$-cstradiol $(2,4,6,7$ ${ }^{3} \mathrm{H}$-estradiol, 3.1-4.1 TBq/mmol) (Amersham), for l6hr at $4^{\circ} \mathrm{C}$. The unbound ligand was removed by adding $0.3 \mathrm{mg}$ of dextran coated charcoal for 10 
min followed by centrifugation at 2500 RPM/ 10 min in an IEC bench-top clinical centrifuge. The supernatant was collected and counted in a liquid scintillation spectrometer. Controls for non-specific binding consisted of samples pre-incubated for $45 \mathrm{~min}$ with $20 \mu \mathrm{g}$ of unlabeled $17-\beta$-estradiol at $4^{\circ} \mathrm{C}$. The ${ }^{3} \mathrm{H}$-ligand was then added and incubated as above. Competition assays using 20hydroxiecdysone (Sigma) were carried out as described above, except that $2 \mu \mathrm{g}$ of the ecdysteroid were added to the incubation mixture.

The F-10 Gene - The gene cloned in the pTZ plasmid vector (GeneScribe-Z), was obtaincd after digestion with EcoRI (Boehringer Mannheim) and purificatied from an agarose gel after eletrophoresis, using the QULAEX kit (Quiagen). Pure F-10 was digested with TaqI restriction enzyme (Pharmacia) and the fragments generated were recovered using the QUIAEX kit. The fragments were dephosphorylated with calf intestinal alkaline phosphatase (Boehringer-Manheim) and end labelled with $\gamma-{ }^{32} \mathrm{P}$-ATP (ICN-Pharmaceuticals) $259 \mathrm{TBq} /$ mmole, using T4 Polynucleotide Kinase (Boehringer Mannheim), according to the manufacturer's instructions

Band-Shift - The labelled fragments were incubated with male or female nuclear extracts for $15 \mathrm{~min}$ at room temperature followed by 15 min at $0^{\circ} \mathrm{C}$, in a final voume of $20 \mu \mathrm{l}$. The binding buffer used contained $10 \mathrm{mM}$ HEPES pH 7.9, $25 \mathrm{mM} \mathrm{CaCl} 2,110 \mathrm{mM} \mathrm{MgCl} 2,1 \mu \mathrm{g}$ acetylated bovine albumin and $1 \mu \mathrm{g}$ of poly $\mathrm{d}(\mathrm{I}) \mathrm{d}(\mathrm{C})$ (Pharmacia). $\beta$-estradiol (SIGMA) and Tamoxifen (ICI), an estrogen antagonist, were incubated in the concentrations indicated in the Figures. After incubation, the samples were fractionated in a $4 \%$ non-denaturating polyacrylamide gel using $1 \mathrm{X}$ TAE buffer $(0.04 \mathrm{M}$ Trisacetate, pH 8.0, l mM EDTA). The gel was dried under vacuum and exposed to $\mathrm{X}$-ray film with an intensifying screcn.

\section{RESULTS}

Figure 1 shows the results obtained by incubating schistosome total protein extracts with ${ }^{3} \mathrm{H}$ $17-\beta$-estradiol. A mean value of $5.8 \mathrm{fmol}$ of estra$\mathrm{diol} / \mathrm{mg}$ protein, was obtained using female protein extracts. Male protein extracts yiclded a value of $4.1 \mathrm{fmol} / \mathrm{mg}$ protein. The differences between the two experimental groups were not significant, however.

Ecdysones, which are known to occur in schistosomes (Nirdé et al. 1983), were also tested in the steroid binding assay. The results are shown in Fig.2. Surprisingly, in the presence of 20-hydroxyecdysone, ${ }^{3} \mathrm{H}$ 17- $\beta$-estradiol binding to the receptors was potentiated several fold in both, male and female protein extracts. The increased bind-

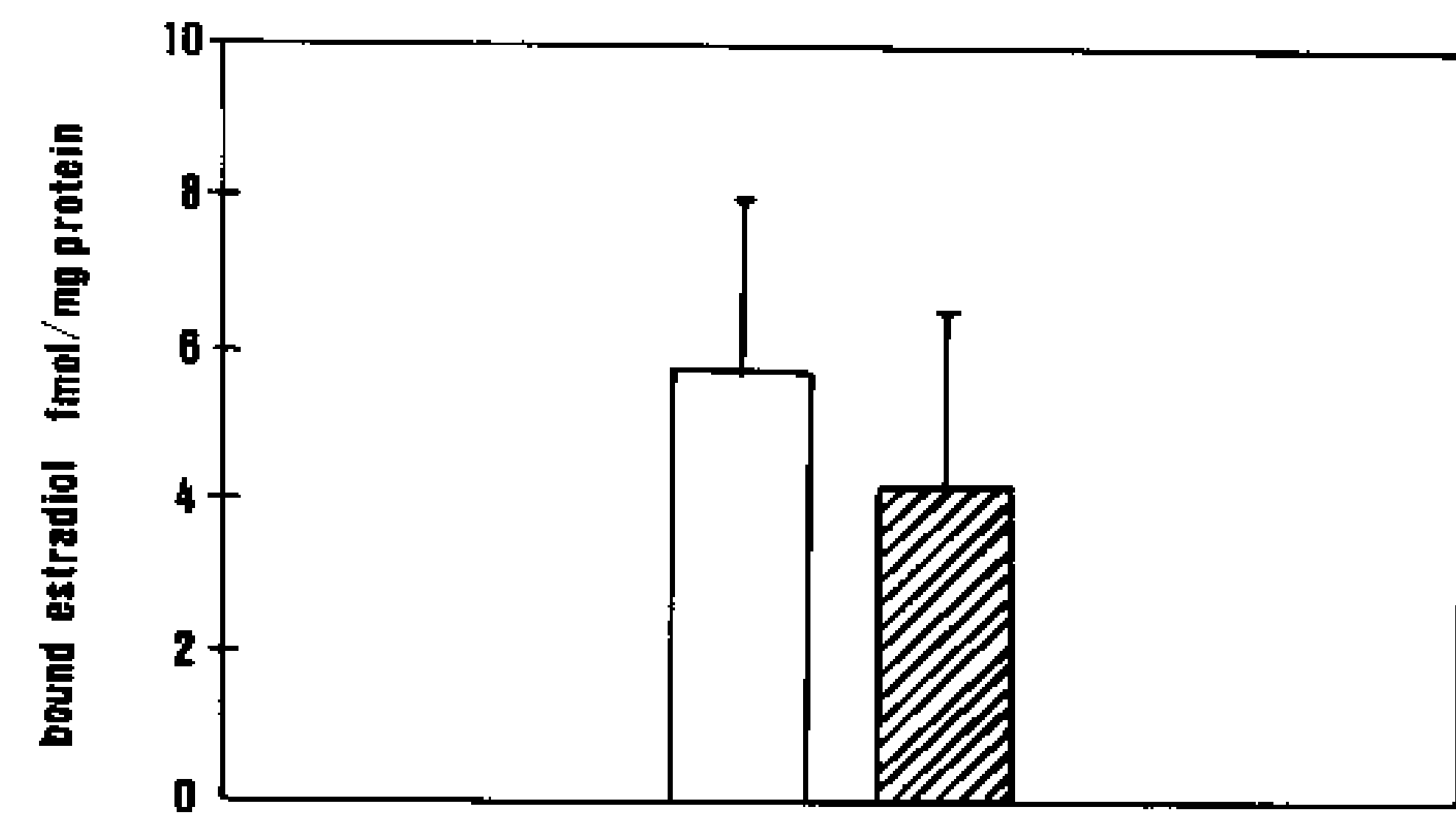

Fig. 1: 17- $\beta$-estradiol binding to proteins from total extracts of Schistosoma manson. Approximately $100 \mu \mathrm{g}$ protein from adult female (open bar) and male schistosomes (hatched bar) were incubated with 88 fmol of the radioactively labelled steroid and processed as described in Methods. The bars represent the mean of seven independent determinations. The standard deviation is represented by the vertical lines.

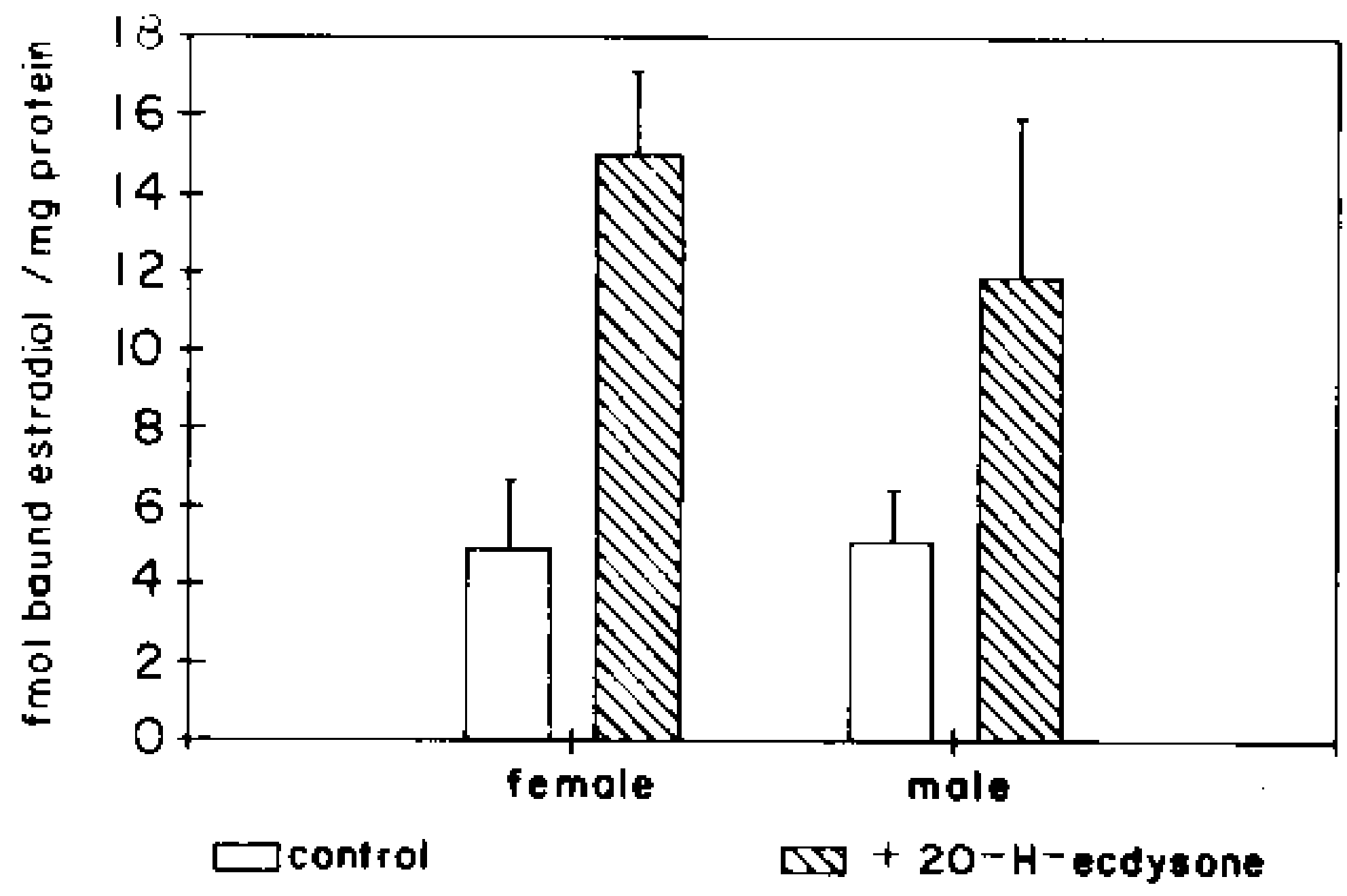

Fig. 2: 17- $\beta$-estradiol binding to proteins of Schistosoma mansont total extracts; effect of 20-hydroxyecdysone. Total extracts from adul1 female and male schistosomes were incubated with ${ }^{3} \mathrm{H} 17$ $\beta$-estradiol alone and estradiol plus 20 -hydroxyecdysone $(2 \mu \mathrm{g})$. as described in Methods. The bars represent the mean of four independent determinations and the vertical lines represent the standard deviation.

ing of estradiol to the protein receptor may have resulted from an allosteric effect .

Figure 3 shows the results of experiments measuring the effect of Tamoxifen and 17- $\beta$-estradiol on the mobility shift of the 5' 107 bp F-10 fragment, caused by male and female nuclear proteins. Female nuclear proteins bound to the $107 \mathrm{bp}$ fragment with a more pronounced effect on the electrophoretic mobility of the complex than that obscrved for the rale nuclear proteins (compare lane 2 with lane 7). Furthermore, nuclear proteins extracted from female worms which had been incubated with Tamoxifen failed to produce the retardation observed in lane 2 . Although band shift of the $107 \mathrm{bp}$ fragment did occur with the nuclear proteins of the Tamoxifen treated female worms, this became similar to that produced by nuclear proteins of male worms (comparc lane 6 to lane 7). Tamoxifen treatment did not affect the mobility shift of the complex formed between male nuclear proteins and the $107 \mathrm{bp}$ DNA fragment 
(compare lane 7 to lane 11). suggesting that the effect of Tamoxifen was directed specifically to female nuclear proteins. The results in Fig. 3 also show that incubation of both live male and female worms with cstradiol did not significantly affect the mobility shift caused by the nuclear proteins of either sex.

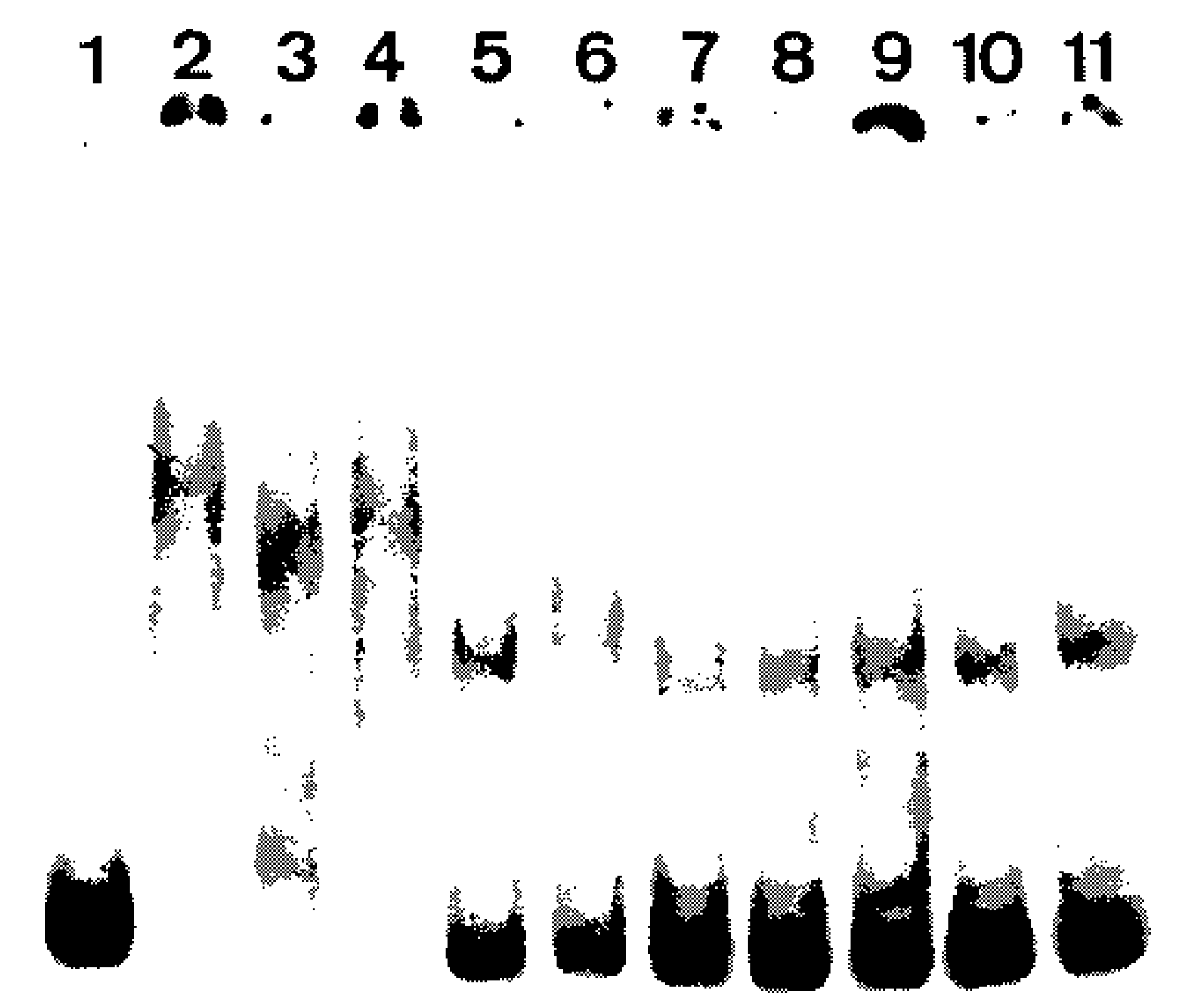

Fig. 3: band-shifl of the $107 \mathrm{bp}$ fragment ( 5 'nd) incubated with Schstosoma mansom nuclear proteins; effect of extradiol and Tamoxilen. Live worms were previously incubated with either $1 \mu \mathrm{M}$ 17-B-estradiol or 1 , M Tamoxifen. Lane l, free DNA tragment: lane 2. JNA $+20 \mu \mathrm{g}$ of lemale proteins; lanes 3 and 4,10 and $20 \mu \mathrm{g}$ respectively of proteins from females inculated with l $1 . \mathrm{M} 17-\beta$-estradiol lanes 5 and 6,10 and $20 \mu \mathrm{g}$ respectively of proteins from females incubated with $1 \mu \mathrm{M}$ lamoxifen; lane 7 $20 \mu \mathrm{g}$ of control male proteins: lanes 8 and 9.10 and $20 \mu \mathrm{g} \mathrm{re}-$ spectively of proteins from males incubated with 1 H.M $17-\beta-\mathrm{es}-$ tradiof: lanes 10 and 11,10 and $20 \mu \mathrm{g}$ respoctively of proteins from males incubated with luM Tamoxifen.

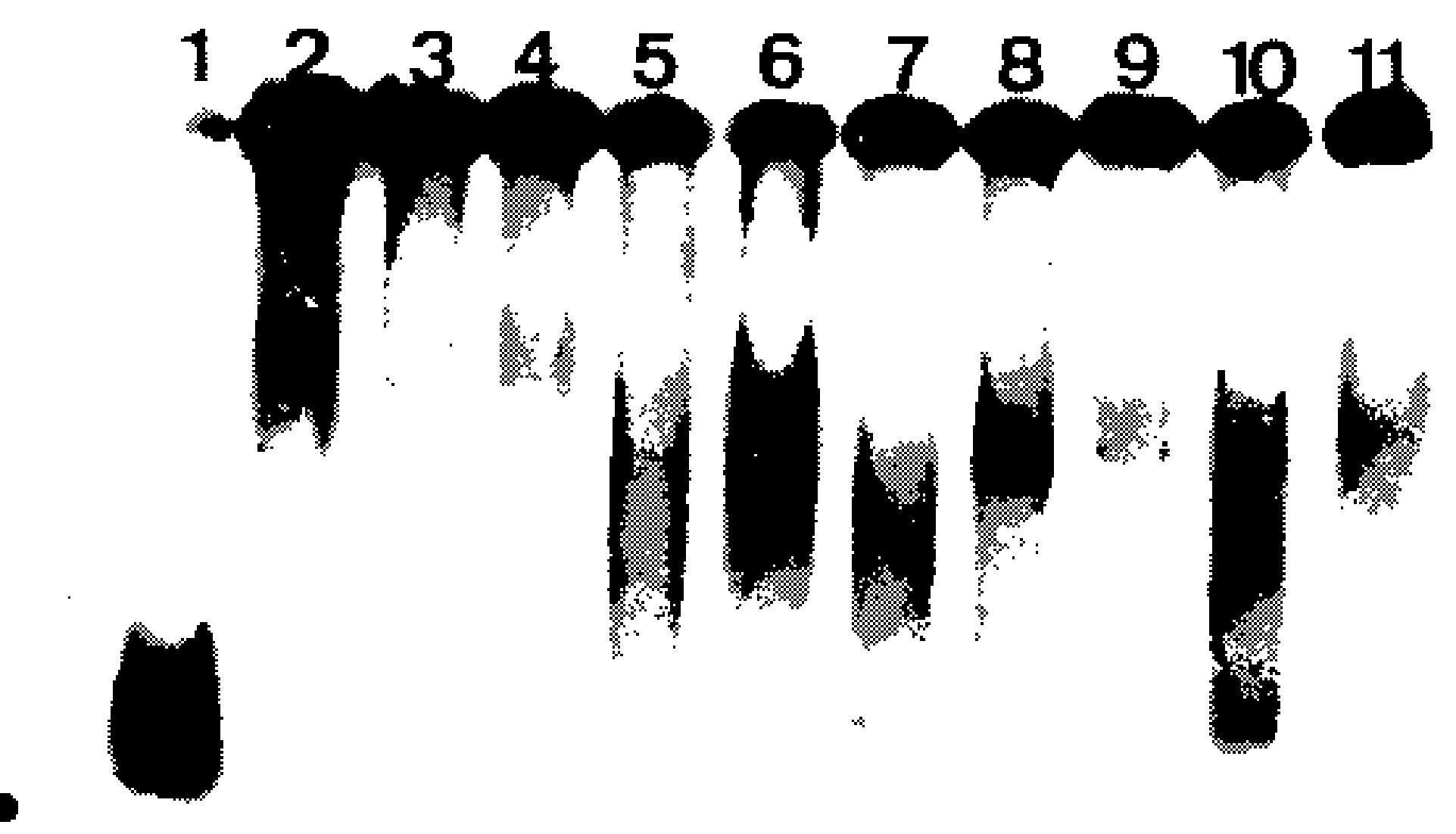

Fig. 4: band-shift of the 306 bp fragment ( 3 end) incubated with Schrstosoma mansoni nuclear proteins; effect of estradiol and Tamoxifen. I ive worms were incubated in the presence of $1 \mu \mathrm{M}$ 17- $\beta$-estradiol or $\mathrm{I} \mu \mathrm{M}$ Tamoxifen, as before. Tane 1 , free fragment; lanes 2-6, female proteins; lanes 7-11, male proteins; lanes 2 and $7,20 \mathrm{~kg}$ of control woms proteins, lanes $3,4.8$ and 9. proteins extracted from worms incubated with $\mathrm{I} \mu \mathrm{M} 17$ - $\beta$-əstradiol; lanes $5,6,10$ and 11 , proteins extracted from woms incubated with l $\mu \mathrm{M}$ Tamoxifen; lanes 3.5 .8 and $10.10 \mu \mathrm{g}$ of protein; lanes $4.6,9$ and $11,20 \mu \mathrm{g}$ of protein.

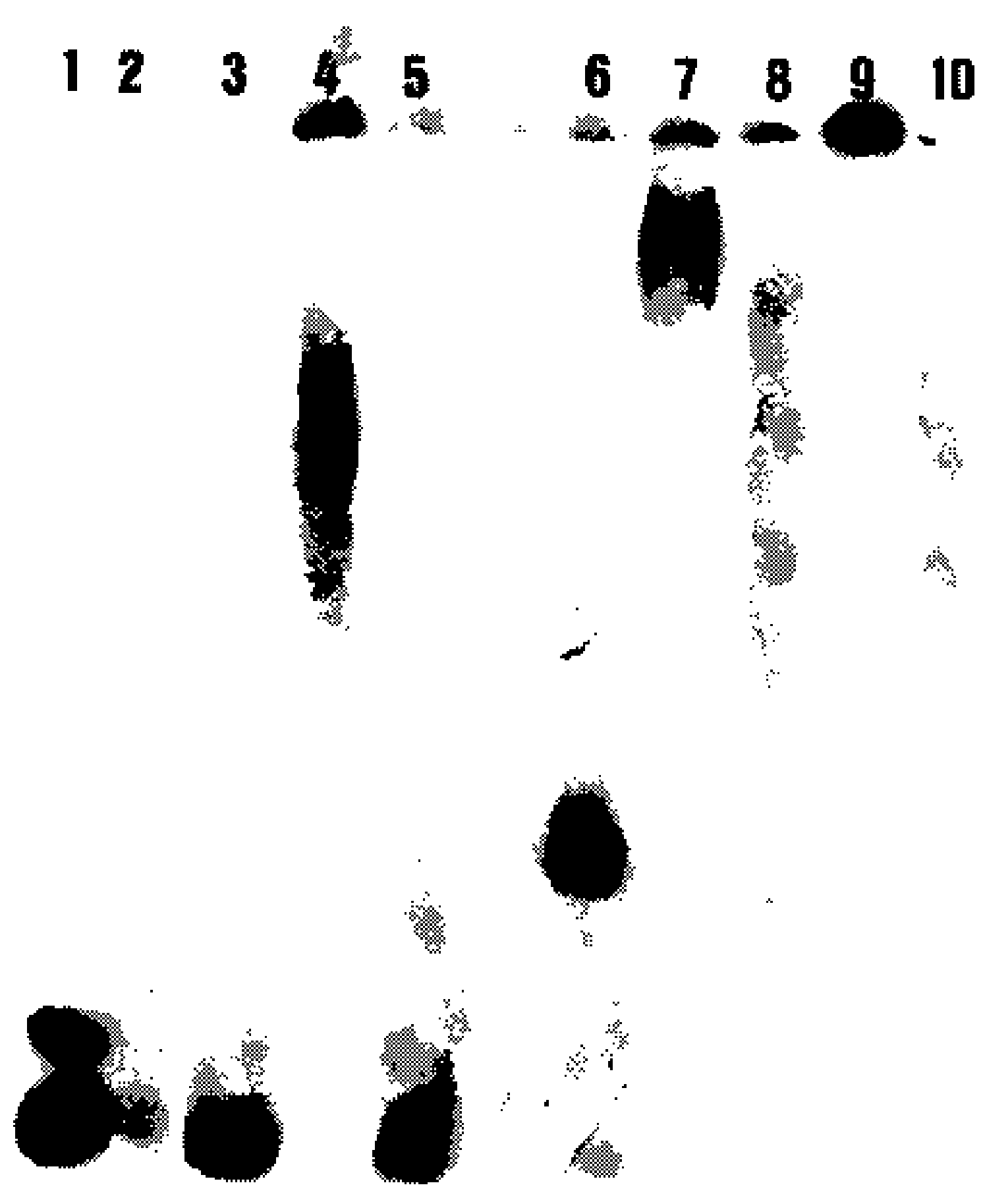

Fig. 5: band-shift of the 107 and $306 \mathrm{lp}$ fragments incubated with the nuclear proteins of male and female parasites: effect of in wo trealment with Tamoxifen. Begining at 5 wecks post-infection, hamsters were injected daily with 100 ug Tamoxifen. The proteins were extracted as described in methods and incubated with the 5 ' and 3 'end DNA fragments. I ane 1 , free 107 bp fragment; lane 2, DNA incubated with female proteins recovered from untrealted animals; lane 3. DN A incubated with female sehistosome proteins recovered from Tamoxilen treated hamsters: lane 4, DNA incubated with male protein preparation from control animals; lane 5 IDNA incubaled with male protein preparation from Tamoxilen treated hamsters; lanes 6-10, same as for lanes 1-5. but incubating the protein with the $306 \mathrm{bp}$ fragment.

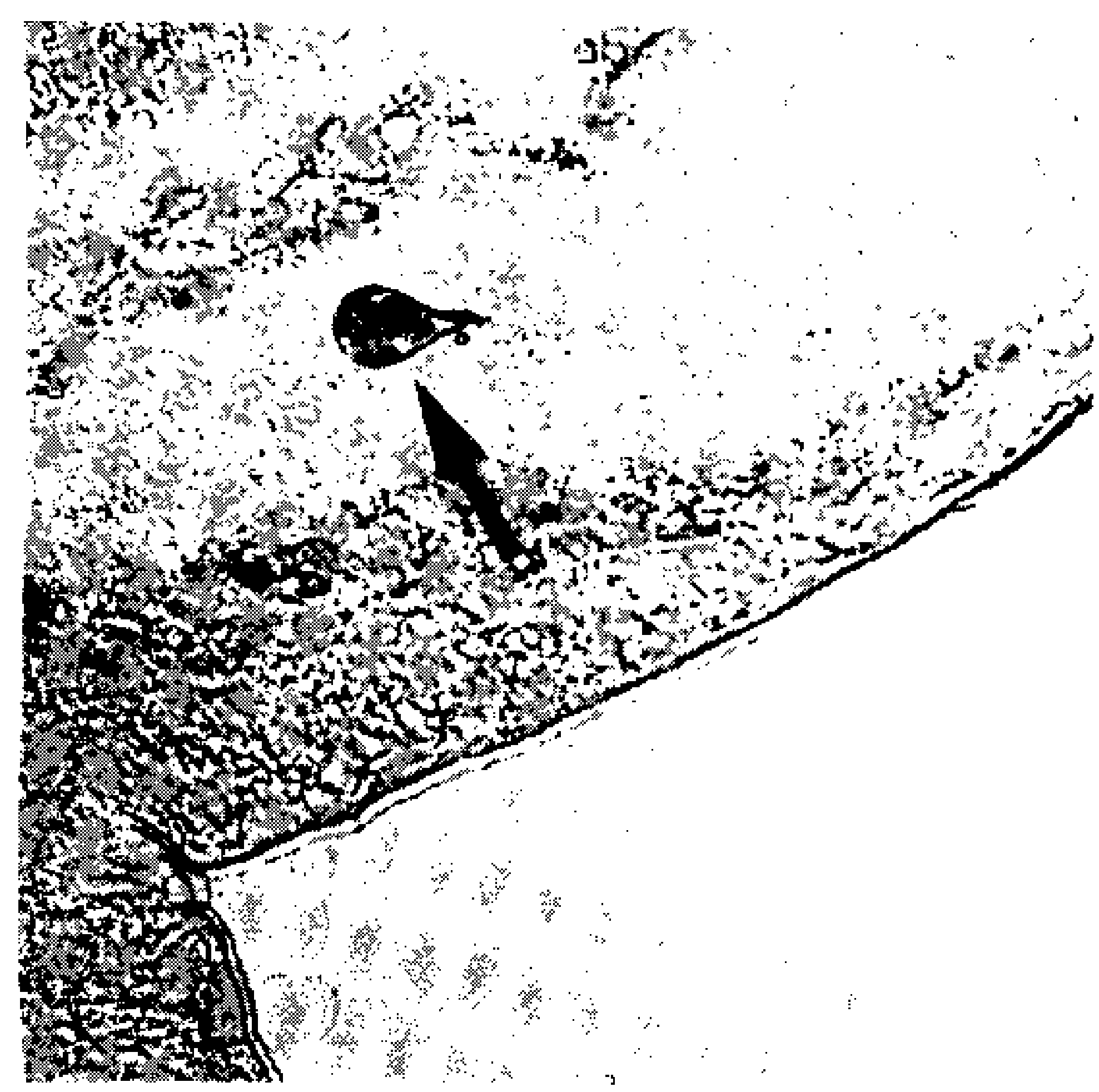

Fig. 6: development of eggs in worms recovered from Tamoxifen treated hamsters. Hamsters were injected daily begining at 5 weeks post-infection, with $100 \mu \mathrm{g}$ of Tamoxifen. The worms wete perfused and examined under a tight microscope at low magnification. The arrow points at an egg displaying abnormal morphology. 


\section{TABI J:}

Fiffect of Tamoxifin on the maturation of female Schistosoma mamsoni

$$
\text { oo of immature females }
$$

$\begin{array}{cc}\text { Tamoxifen } & 54 \\ \text { Control } & 8\end{array}$

Schistosoma mansomi infected hamsters were injected daily with $100 \mu \mathrm{g}$ of Tamoxifen begining at five wecks after infection. The worms were perfissed and observed in a light microscope at low magnification. 'The number of stunted worms lacking vitelline glands was then counted.

The same type of experiment was carricd out with the 3 ' end. 306 bp F-10 fragment. containing the steroid regulatory element. The results are shown in Fig.4. Again it can be seen that nuclear proteins obtained from female proteins produced a distinct pattern of binding, when compared to
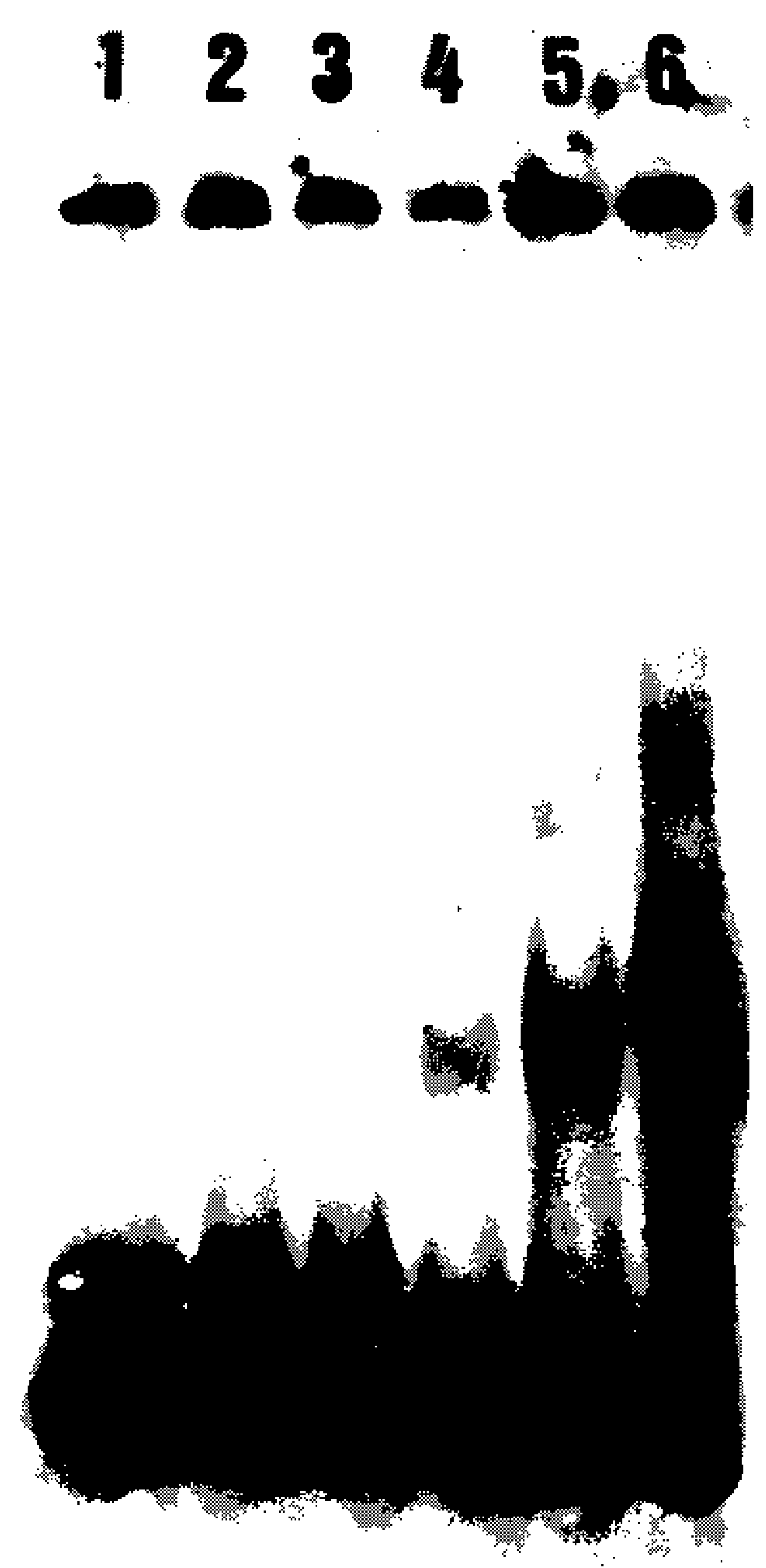

Fig. 7: band-shift of the $107 \mathrm{bp}$ fragment incubated with the alligel 501-purified nuclear proteins from a mixed sex population. Lane 1 , tree fragment; lanes 2 and 3 . DNA incubated with 10 and 20 $\mu \mathrm{g}$ respectively, of unbound proteins: lanes 4 and 5. DNA incubated with 10 and $20 \mu \mathrm{g}$ respectively, of proteins retained and eluted from the column (containing SH groups); lane 6, DNA $+20 \mu \mathrm{g}$ of total male nuclear protein. the male protcins (lane 2 and lane 7). Also, pretreatment with Tamoxifen abolished the femalespecifie shift as shown in Fig. 4 , lane 6. Although the complex observed in lane 6 did not form a sharp band. it did not comigrate exactly with the complex produced by proteins from untreated male worms (lane 7), as observed for the $107 \mathrm{bp}$ fragment. By comparing lane 710 lanes 8.9 and 10 , it can also be seen that estradiol and Tamoxifen. albeit discretely, affected the mobility shift produced by the male protein extract. The effect of Tamoxifen was also studied in vivo, by injecting the drug into S.mansoni infocted hamsters. extracting the nuclear proteins from adult worms and incubating them with the $107 \mathrm{bp}$ and $306 \mathrm{bp} \mathrm{F-10}$ fragments for the band-shift experiments. The results are shown in Fig.5. It can be seen that Tamoxifen affected the interaction of proteins with the DNA in both preparations (lanes 3, 5,8 and 10). Curiously, in these experiments, the gel shift retardation effect of both protein preparations (male and female), was abol-
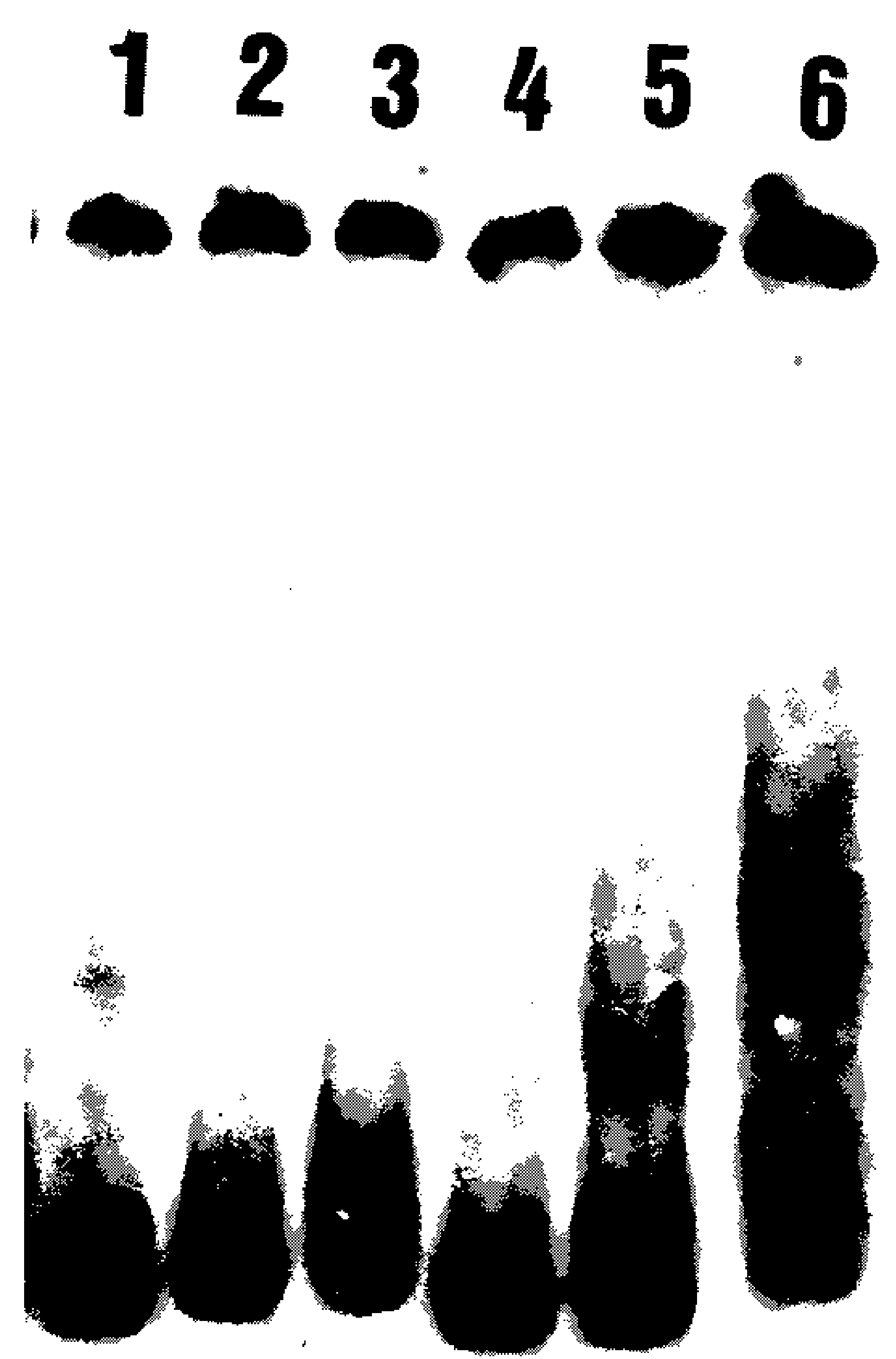

Fig. 8: band-shift of the $306 \mathrm{bp}$ fragment incubated with the affigel 501-purified nuclear proteins from a mixed sex population. I ane 1 , free fragment; lanes 2 and $3.1 \mathrm{Y} \times \mathrm{A}$ incubated with 10 and 20 ag respectively of unbound proteins; lanes 4 and 5,10 and 20 ig respectively of the proteins retained and eluted from the column; lane 6 . IDN $A+20 \mu g$ of total male nucleas protein. 
ished by Tamoxifen. However, using another approach, Tamoxifen was shown to exert its effect primarily on females. Two main features could be observed: (a) S. mansoni infected and - Tamoxifen
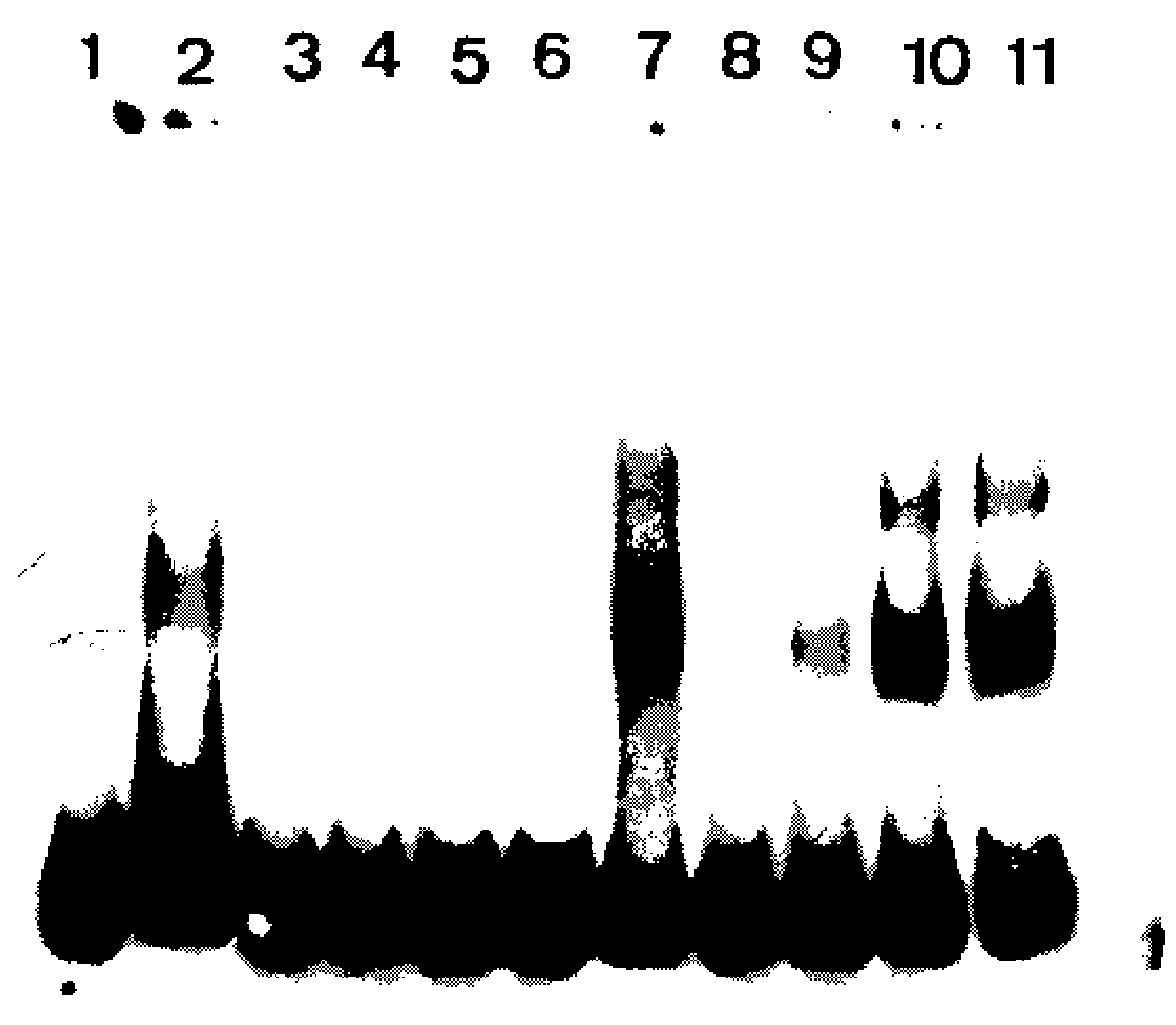

Fig. 9: band-shift of the 107 bp fragment incubated with the affigel $50 \mathrm{i}$-purified nuclear proteins from male and female worms. I.ane 1, free fragment; lane 2, DNA fragment was incubated with $20 \mathrm{\mu g}$ of female nuclear protein prior to aflinity chromatography; lanes 3 and 4, the DN $A$ was incubated with 10 and $20 \mu \mathrm{g}$ respectively, of proteins extracted from females which did not bind to the affi-gel column; lanes 5 and 6 . the IDNA fragment was incubated with female proteins retained by the column: lane 7. DNA fragment incubated with $20 \mu \mathrm{g}$ protein from male worms, prior to affinity chromatography; lanes 8 and $9, \mathrm{DNA}-10$ and $20 \mu \mathrm{g}$ respectively of unbound male protein; lanes 10 and 11 , DNA + 10 and $20 \mu \mathrm{g}$ of bound male protein.
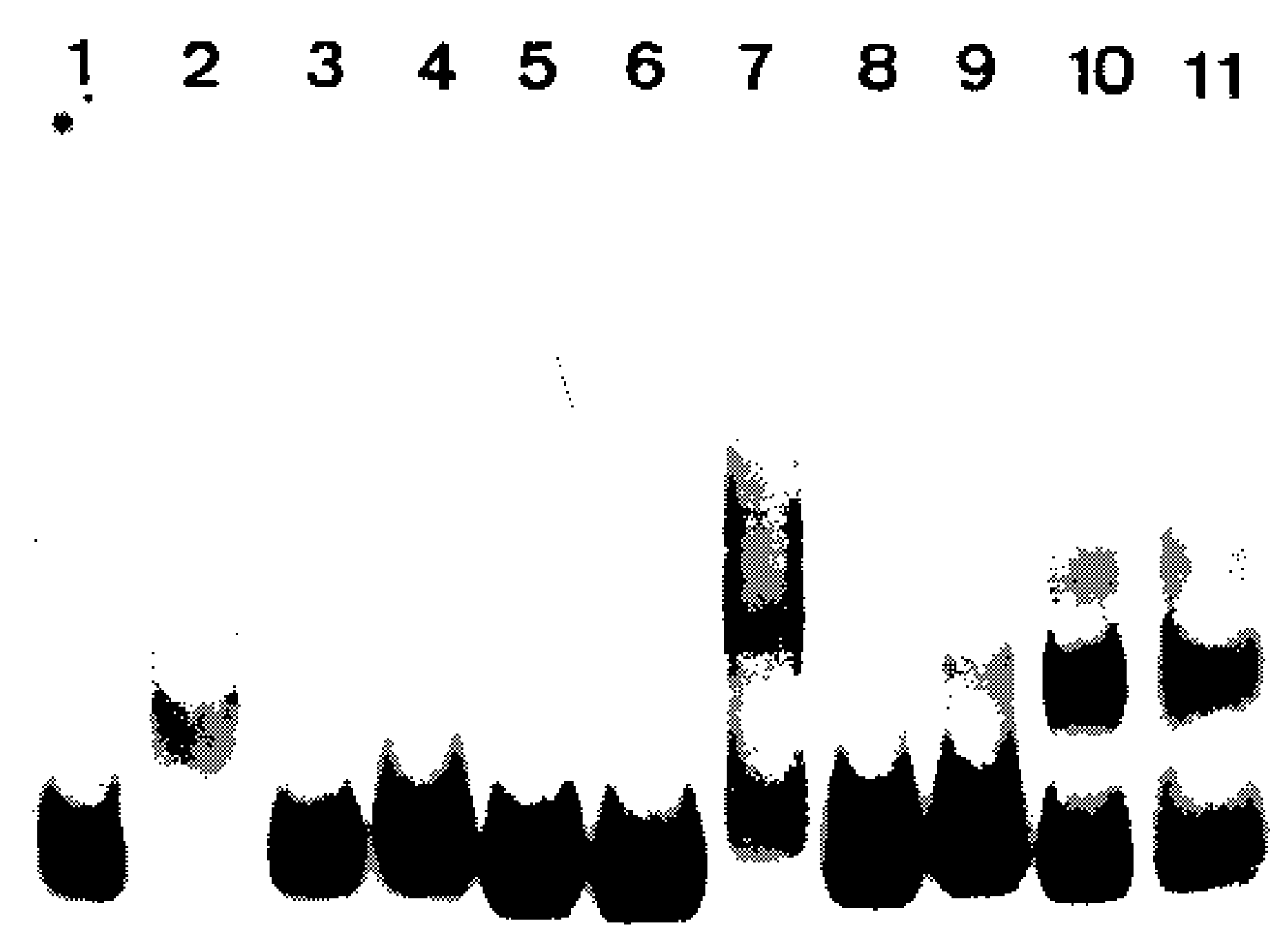

Fig. 10: band-Shift of the 306 bp fragment incubated with the affigel 501-purified nuclear proteins from male and female worms. Lane 1, free fragment; lane 2. DN $\wedge$ fragment was incubated with $20 \mu \mathrm{g}$ of female nuclear protein prior to affinity chromatograpiy. lanes 3 and 4 , the DNA was incubated with 10 and $20 \mu \mathrm{g}$ respectively, of unbound proteins extracted from females which did not bind to the affi-gel column; fanes 5 and 6, the DNA fragment was incubated with fenale proteins retained by the column: lane 7 , DNA fragment incubated with $20 \mu \mathrm{g}$ protein from male worms, prior to affinity chromatography: lanes 8 and 9, DNA 10 and $20 \mu \mathrm{g}$ respectively of unbound male protein; lanes 10 and 11, DNA -10 and $20 \mu \mathrm{g}$ of bound male protein. injected hamsters, displayed a higher rate of immature females, as shown in Table; (b) The eggs of worms recovered from hamsters injected with the anti-estrogen presented gross morphological anomalies, as shown by the arrow in Fig.6. No noticeable effects of Tamoxifen on male parasites could be detected.

In order to investigate whether the binding of the schistosome nuclear proteins to the F-10 fragments was dependent on the zinc finger structural motif of steroid receptors (containing thiol groups), the nuclear extract was chromatographed on a AFFI-GEL 501 affinity column, prior to the gel mobility assay. This resin displays affinity for thiol groups. The results obtained with the 5', $107 \mathrm{bp}$ fragment are shown in Fig.7. It is clear that only those proteins retained by the AFFI-GEL column were able to bind to the DNA fragment (lanes 4 and 5). A similar result was obtained with with the 3' end, $306 \mathrm{bp}$ fragment (Fig.8), where it is cvident that only those proteins retained by the matrix produced a band shift (lane 5 ).

When male and femalc nuclear proteins were chromatographed separately on the AFFI-GEL column, band shifts wcre observed mainly with retained proteins extracted from male worms, as shown in Fig. 9, lanes 10 and 11. In lane 9, the $107 \mathrm{bp}$ fragment was shifted to the same position after incubation with the unbound proteins. The absence of a shift observed with both female, bound and unbound proteins (Fig. 9, lanes 3-6) was intcrpreted as duc to loss of protein during the chromatographic procedure. Similar results were obtained with the 3 'end fragment, as shown in Fig. 10.

\section{DISCUSSION}

The ligand binding experiments using crude extracts of male and femalc schistosomes incubated with ${ }^{3} \mathrm{H} 17-\beta$-estradiol and 20 -hydroxyecdysteroid suggested the occurrence of steroid receptors. The apparent potentiation of 20-hydroxyecdysone on estradiol binding indicated that the schistosome putative estrogen receptor could be modulated by other steroids.

Using the gel mobility assay we were able to establish that proteins in nuclear extracts of adult schistosomes, bound to the gene F-10. Among these proteins, some were only found in female nuclear protein extracts.

The binding of female schistosome nuclear protcins to the fragments corresponding to the $5^{\prime}$ and 3 ' ends of the gene F-10 was shown to be influenced by Tamoxifen. an estrogen antagonist both, in vitro and in vivo. In vitro, this effect of Tamoxifen was restricted to the femalc protein extracts. On the other hand, Tamoxifen injected into hamsters was shown to affect both, the development of 
females and of eggs, as indicated by pronounced morphological alterations. These effects of Tamoxifen could have been explained by inhibition of protein biosynthesis, a known property of the anti-estrogen. However, control experiments (not shown) failed to demonstrate a decreased incorporation of $35 \mathrm{~S}$-methionine onto proteins of Tamoxifen-treated parasites, thus suggesting that the drug may have exerted its effect by blocking the access of the schistosome nuclear proteins to steroid receptors. Other results strenghtening the argument for the occurrence of steroid receptors among the nuclear proteins, were obtaincd from the affinity chromatography experiments using the AFFI-GEL matrix. These experiments showed that the binding of the proteins to the different fragments of the F-10 gene, seem to require thiol groups, and therefore, clusters of cysteine residues. The occurrence of these cysteine clusters is consistent with the occurrence of zinc-fingers, a structural feature of steroid receptors.

Whereas unpurified female and malc purified cysteine containing proteins were clearly able to produce a shift with the $5^{\prime}$ and $3^{\prime}$ fragments, this effect was not observed with either the retained and unretained fractions of the female protein preparation.

Taken together, the results in this paper make a case for the occurrence of steroid receptors in schistosomes.

\section{ACKOWLEDGEMENTS}

To expert technical assistance of Mrs Sonia Cristina Freire and Ms Maria Marta Freire.

\section{REFERENCES}

Bobek I,A, Lo Verde P'T, Rekosh DM 1989. Schistosoma haematobium: Analysis of eggshell protein genes and their expression. Exp Parasitol 68: 17-30

Bobek LA, Rekosh DM, Lo Verde PT 1991. Schistosoma japonicum: Analysis of eggshell protein genes, their expression and comparison with similar genes from other schistosomes. Exp Parasitol 72: 381-390.
Chen L, Rekosh DM, Lo Verde PT 1992. Schistosoma mansoni p48 eggshell protein gene: characterization, developmentally regulated expression and comparison to the pl4 eggshell protein gene. Mol. Biochem Parasitol 52: $39-52$

Engelender S. Giannini ALM, Rumjanek FD 1993. Protein interactions with a gender-specific gene of Schistosoma mansoni: characterization by DNase I footprinting, band-shift and UV cross-linking. Mol Cell Biochem 124: $159-168$

Henkle KJ, Cook GA, Foster I.A. Fngman DM. Bobek LA, Cain GI, Donelson JE 1990. The gene family encoding eggshell proteins of Schistosoma mansoni. Mol Biochem Parasitol 42: 69-82

Kunz. W, Opatz K, Finken M, Symmons P 1987. Sequence of two genomic fragments containing an identical coding region for a putative eggshell precursor protein of Schistosoma mansoni. Nucl Acids Res 15: 5894.

Lowry OH, Rosenbrough NJ, Farr AI , Randall RJ 1951. Protein measurement with the Folin phenol reagent. $J$ Biol Chem 193: 265-275.

Nirde P, Torpier G, De Reggi ML, Capron A 1983 Fedysone and 20-hydroxyecdysone: New hormones for the human parasite Schistosoma mansoni. FEBS Letters 151: 223-227

Rickwood D, Hames BD 1990. Gel electrophoresis of nucleic acids, a practical approach, p. 225-248. In GH Goodwin. The analysis of sequence-specific DNA-binding protein in cell extracts, Oxford University Press, New York

Rumjanek Fl), 3raga VMM, Kelly C 1989. DNA binding proteins of Schistosoma mansoni recognizing an hexanucleotide motif occuring in genes regulated by steroids. Comp Biochem Physiol 94: 807 812 .

Simpson AJG, Chaudhri $M$, Knight $M$, Kelly $C$, Rumjanck FD, Martin S, Smithers SR 1987. Characterization of the structure and expression of the gene encoding a major female specific polypeptide of Schistosoma mansoni. Mol Biochem Parasitol 22 . 169-176.

Smithers SR, Terry RJ 1965. The infection of laboratory hosts with cercariae of Schistosoma mansoni and the recovery of adult worms. Parasitology 55: $695-700$. 